\title{
Bunds historia framstår som både avslutad och högaktuell
}

\author{
BoKRECENSION
}

DOI: https://doi.org/10.30752/nj.103425

Håkan Blomqvist: Socialism på jiddisch: judiska Arbeter Bund i Sverige (Stockholm: Carlssons, 2020), 237 s.

När den central- och östeuropeiska judenheten, invånarna i jiddischland, mötte modernitetens existentiella och politiska utmaningar bildades Bund, Der algemeyner yidisher arbeter bund in Lite, Poyln un Rusland. Samma år, I 897, hölls den första sionistiska världskongressen i Basel och året därpå bildades Rysslands socialdemokratiska arbetarparti som senare splittrades i bolsjeviker och mensjeviker. Samtidigt som en massiv antisemitism ständigt hotade den judiska minoriteten i det ryska imperiet fanns det en stark tro på emancipationen, frigörelsen stod för dörren. Frågan var bara vilken frigörelse moderniteten möjliggjorde. Bund utgjorde, i likhet med sionismen och den assimilationistiska kommunismen, ett distinkt alternativ för de judar som inte ville sätta sitt hopp till de traditionella religiösa frälsningsvägarna.

Det är inte många som relaterar Bund och dess historia till Sverige men historikern Håkan Blomqvist har i Socialism på jiddisch: judiska Arbeter Bund i Sverige tagit sig an att skriva Bunds historia i Sverige. Boken är ganska liten. På 225 sidor ges först en kompakt introduktion till Bunds historia i stort. Sedan följer boken det svenska Bund som grundas före kriget men som till allra största delen bestod av polsk-judiska flyktingar som kom

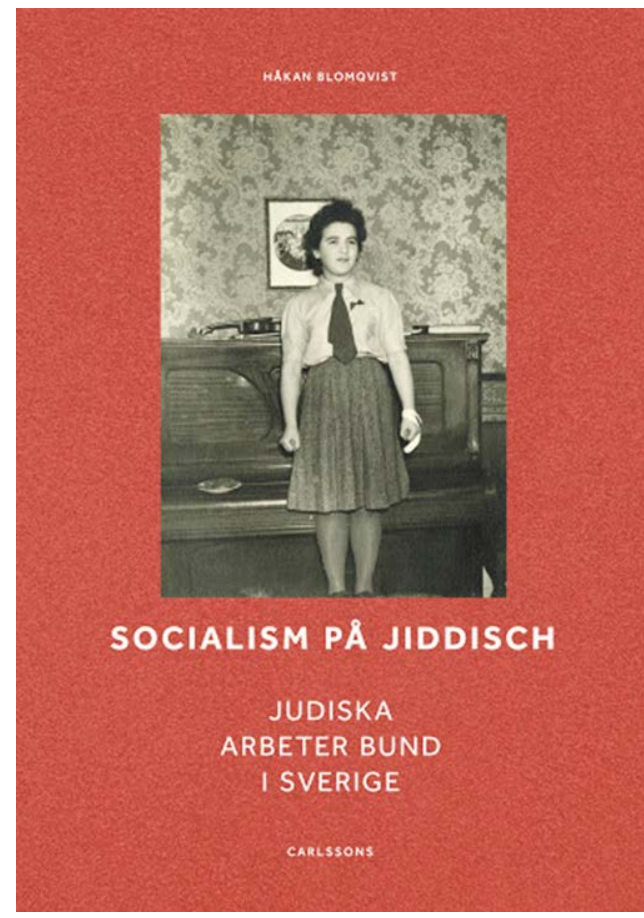

till Sverige kort efter kriget. Det skulle kunna tolkas som att boken är tunn på grund av att den behandlar ett perifert ämne men på dessa sidor presenteras en mångfasetterad historia, en mikrohistoria som bär med sig r 9oo-talets stora historiska, politiska och existentiella frågor. Bunds egentliga historia i Sverige inleds vid krigsslutet när den kultur som utgjorde grunden för massrörelsen blivit förstörd, mördad. Kvar fanns bara spillror av den forna massrörelsen som tidigare hade haft en uppsjö av olika uttryck, från sanatorier och kulturföreningar till ungdomsverksamhet 
och beväpnad försvarsmilis. I Polen under mellankrigstiden gick det att leva ett helt liv inom Bunds olika verksamheter.

Utöver att Bund var en socialistisk rörelse förespråkade de doykait, härhet, vilket innebar att de såg framför sig en framtid i Europa för den europeiska judenheten. Till skillnad från bland annat kommunisterna förespråkade Bund inte assimilation utan ville istället verka för en stark sekulär jiddisch-judisk kultur som i samverkan med andra grupper kunde bygga ett socialistiskt samhälle. De tog starkt avstånd från både sionismen och en religiöst baserad judendom. Bund krossades onekligen i grunden, främst av de tyska nazisterna och deras kollaboratörer men även av de sovjetiska kommunisterna. Bunds självständiga verksamhet förbjöds av Bolsjevikerna vid deras maktövertagande i Ryssland I9I7. Efter det inledde Bund sin andra storhetstid i det nybildade Polen. När andra världskriget inleddes och Polen delades mellan en sovjetisk och en tysk ockupation förbjöds och förföljdes Bund i båda. Även efter kriget motarbetades Bunds försök till återuppbyggnad av den nya polska regimen under Stalins kontroll. Återvändande polska judar utsattes efter kriget för en stor mängd antisemitiskt våld, vilket pogromen i Kielce I946 är det mest kända exemplet på. Denna omständighet bidrog ytterligare till rörelsens svårighet att återforma sig i Polen. Bund tillhör onekligen historiens förlorare, mördade och fördrivna från det som Timothy Snyder kallar den blodiga jorden mellan Hitler och Stalin. Trots detta kan dessa förlorares erfarenheter, deras ställningstaganden, deras självförsvar, gemenskap, solidaritet och rörelse föreslå något för oss idag medan deras besegrare framstår för världen som de cyniska massmördare de var.

Socialism på jiddisch är ett betydelsefullt verk som fyller en så kallad lucka i historieskrivningen. Blomqvist använder källmaterial som hittills inte använts och som bidrar med ny kunskap om arbetarrörelsens historia, efterkrigstiden, svensk flyktinghistoria, Förintelsen, svensk-judisk historia, antisemitism, jiddisch-kultur etcetera. Den för också in relevanta perspektiv från nationalismforskning som visar Bunds förhållningssätt till det nationella i ett nytt ljus. Den historievetenskapliga gärningen är uppenbar men det går även att göra en läsning som fokuserar på de centrala frågor som väcks i Socialism påjiddisch snarare än de frågor som besvaras. Frågorna jag finner i boken är både historievetenskapliga och rent existentiella, etiska och politiska. Vad kan vi lära oss av den historia som Håkan Blomqvist presenterar i boken? Eller snarare, hur ska vi reagera på den utmaning som historien om Bund riktar mot oss?

Det är svårt att inte få sympati för Bund i Blomqvists skildring. Som läsare vill man dem väl, att de ska bli framgångsrika. Trots att historien onekligen visade att doykait $\mathrm{i}$ stort ledde till döden, trots att hela det jiddischland som Bund tillhörde och kämpade för var dödsdömt, kan deras kamp framstå som det rätta alternativet. Doykait kan läsas som ett existentiellt tidlöst ställningstagande i stil med gräv där du står. Det understryker människors rätt att utveckla sin identitet, sin kulturella tillhörighet och även sin sociala gemenskap och trygghet där de lever nu. Samtidigt som den egna kulturen värnas om finns det ingen vision om en kulturellt homogen nationalstat. Förutsättningen för doykait är därmed att kunna leva i fredlig och jämlik samvaro med andra grupper. Som förhållandena var kring antisemitismen under Bunds storhetstider, både i det ryska imperiet och det självständiga Polen, krävdes det ett starkt judiskt självförsvar för att försöka upprätthålla en fredlig samexistens. Bund reagerade på ett intersektionellt förtryck, samverkan av klassförtrycket och antisemitismen, långt före begreppet intersektionalitet myntades. 
Utöver dessa storskaliga politiskt historiska ödesfrågor lyfter Socialism på jiddisch även personliga livsöden som vi fär komma nära. Ibland handlar det om betydelsefulla historiska aktörer för Bunds historia i Sverige som Paul Olberg eller Sara Mehr; personer som bedriver en frenetisk verksamhet mellan organisationer i Sverige, Europa och USA för att hjälpa flyktingarna och verka för saken. Vi får även möta personer som enbart tittar fram på något fotografi eller som genom ett fåtal bevarade brev kan rekonstrueras tillräckligt för att måla konturerna av ett livsöde. Dessa personer ger en levande föraning om hela det universum av livsöden som passerade genom Bund-kollektiven och förläggningarna åren efter kriget.

Socialism på jiddisch är också en arkivnära studie som i detta avseende kan tillfredsställa många historiker. Håkan Blomqvist lyckas kombinera det vetenskapliga idealet om metodologisk transparens med en läsvänlighet där vi får följa med i arkivarbetet och möta en stor mängd illustrativa citat som uttrycker högt som lågt, från personliga gräl till tankar om världspolitiken. Vid ett fåtal tillfällen träder Blomqvist in i en dialog med historievetenskapliga tankar. Framför allt i slutet av boken relaterar han Bund till Benedict Andersons sönderciterade men ändå användbara Den föreställda gemenskapen. När nationella berättelser och myter ifrågasätts i en alltmer globaliserad värld och nationalismerna framstår som resultatet av det styrande skiktets ideologiska produktion framstår Bunds hållning som aktuell, rent utav som en föregångare till ett mer senmodernt politiskt tänkande.

Bunds historia tillhör givetvis den judiska historien men lika mycket utgör den en central del av arbetarrörelsens historia. Blomqvist relaterar Bund till de så kallade austromarxisternas ideologi som inte heller ville förverkliga socialismen $\mathrm{i}$ avskilda nationalstater till skillnad från övriga marxistiska rörelser under perioden. Utöver det ideologiska perspektivet är Bund ett betydande studieobjekt för arbetarrörelsens historia genom sin omfattande storlek, sin mångfasetterade karaktär av massrörelse och genom att det grundas så tidigt. För att vara en politisk rörelse av den storlek och betydelse som Bund var så verkar rörelsen ha förvånansvärt få skelett i garderoben.

Socialism på jiddisch presenterar en mikrohistoria som lyckas visa på det stora i det lilla och det lilla i det stora. Den lyckas knyta an historien till vår samtid och genom specifika människoöden väcka känslor utan att det storskaliga historiska perspektivet glöms bort. Bland annat följer Blomqvist med jiddischpoeten Irena Klepfisz som återbesöker Neglinge utanför Stockholm, efter 70 år, där hon och hennes mor bodde i ett Bundkollektiv innan de tog sig vidare till New York. Sverige blir i dessa exempel en tillfällig viloperiod som i deras skildringar kan spä på föreställningar om den svenska exceptionalismen. Kontrasten blir slående mellan krigets Polen och den idylliska villastaden i det krigsförskonade Sverige. Samtidigt visar Blomqvist också på känslan av ensamhet, isolering och uppgivenhet i Sverige. Exilens villkor leder till irritation, konflikter och känslor av hopplöshet. Detta är ett tillstånd som många människor i exil delar med bundisterna. Engagemanget finns men det har uppstått en oöverstiglig distans till det som kampen en gång gällde. I exilen blir den familjära bundistiska gemenskapen mischpoke det allra viktigaste; en sista kontakt med de sina, något som finns kvar från den gamla världen före förstörelsen. Det är lätt att göra misstaget att betrakta en politisk rörelse som en enbart politisk rörelse. Politiska rörelser i allmänhet och Bund i synnerhet är också sociala gemenskaper, människor som upplever khavershaft, kamratskap, och fyller sin 
tillvaro med mening genom en rad olika gemensamma aktiviteter inom rörelsen.

Boken är på många sätt en tragedi, eller kanske en efter-tragedi. Den stora katastrofen klaras av redan i det inledande bakgrundskapitlet. Bunds historia i Sverige handlar om att leva och verka efteråt. Det blir till en återhämtning, ett försök att samla sig och återanknyta till den bundistiska gemenskapen som även den går mot en andra upplösning. Kapitlen i den andra halvan av boken bär namn som "Prövningarna", "Sönderfallet", "Splittringen" och "Slutet".

Boken avslutas dock med kapitlet "Efteråt” som understryker att Bunds historia i huvudsak är över och att de judiska flyktingar som utgjorde Bund i Sverige med tiden hade sökt sig vidare till andra platser som USA, Australien, Frankrike och, vilket kan tyckas paradoxalt men ändå klart begripligt, till Israel. På dessa platser har Bund fortsatt mest som en minneskultur fram till idag. Blomqvist visar dock på några tendenser till en bundistisk renässans.

Boken väcker en uppsjö av frågor. Kan vi betrakta Bund före Förintelsen på ett rättvist sätt? Var strategin om doykait ett hopplöst projekt? Var målsättningen om en socialistisk judisk emancipation i jiddischland naiv? Går det att döma med facit i hand? Har historien visat att judiskt liv i Europa i grunden är ett livsfarligt projekt? Var Bund på väg att skapa en emanciperad, livfull och trygg judisk kultur i Europa? Ger exemplet Bund argument för eller mot multietniska stater och kulturell mångfald? Kan en förlorad kamp som avslutades i en katastrof ändå ha varit rättfärdig?

Det är svårt, för att inte säga omöjligt, att idag leva sig in i bundisternas tillvaro före andra världskriget utan att Förintelsens skugga faller över hela det historiska sammanhanget. Genom att acceptera denna aspekt av vår förståelsehorisont kan vi åtminstone intala oss att vi inte klarar av att betrakta livet i jiddischland före andra världskriget i sin egen rätt, som något annat än det sista kapitlet i denna kulturs historia. Vi möter deras frenetiska ideologiska diskussion om framtida emancipation med en sorgsen blick. Utifrån det konstaterandet kan vi sedan återvända till Bund under dess storhetstider i ett försök att åtminstone ta deras ställningstaganden på allvar.

Håkan Blomqvists historiska skrivande utgör en intressant kombination av grundligt arkivarbete och en personlig röst som utgår från ett eget engagemang $\mathrm{i}$ frågorna han skriver om. Han betraktar inte historien ovanifrån från en sval lounge i det berömda elfenbenstornet. I stället brottas han själv med de existentiella och politiska frågor som historien ställer. I den andan avslutas boken med att lyfta fram Bunds försök att demokratiskt hantera spänningen mellan universalism och partikularism, mellan nationell utopism och pragmatisk doykait. Den politiska vänstern har idag återvänt till en kritik av nationalstatstänkandet. Behovet av att förhålla sig till nationalism och minoritetskultur, etnisk och social rättvisa, pluralism, klassklyftor, antisemitism och annan rasism, alla dessa frågor är lika aktuella som när Bund grundades.

Bund, såväl det internationell som det svenska, är en bruten rörelse men i Håkan Blomqvists levande skildring av den Socialism på jiddisch: judiska Arbeter Bund i Sverige upplevs deras strävan och erfarenheter som aktuella och relevanta. Jag ser fram mot den fortsatta diskussionen.
MARTIN ENGLUND Doktorand i historia Södertörns högskola 